Mr Boswell, rightly suspecting this episode to belong to a form of the Transitus Mariae fuller than any he had seen, has not been able to point to its occurrence in any text. So far as I can see, it only occurs in that remarkable Syriac form of the legend which is to be found in Wright's Syriac Apocrypha under the name of the Obsequies of the Holy Virgin. On p. 47 is this passage :-

'The dreadful place of torment which the Disciples begged of our Lord that they might see.

'And when these things were said by the blessed Apostles, our Lord made a sign with His eyes, and a cloud snatched away the Apostles and Mary and Michael, and our Lord along with them, and carried them to where the sun sets, and left them there. And our Lord spake with the angels of the pit, and the earth sprang upwards, and the pit was revealed in the midst of the earth. And our Lord gave place to the Apostles, that they might look, as they were wishing.' Then follows a scene of intercession for those in torment, of which the conclusion is wanting.

The question whether Oriental literature was indeed known in Ireland in early times has never been properly worked out. It is stated by $\mathrm{Dr}$ G. T. Stokes that the Saltair ma Rann contains passages from the Oriental Book of Adam and Eve. As the text of the Saltair has never been translated, it is impossible for me to say whether the Oriental book or the Latin Vita Adae is really the source of the passages in question. At present, the quotation from the Obsequies given above is the clearest instance that I have encountered of obligation on the part of an Irish writer to an Oriental text.

M. R. JAMRS.

\title{
TWO MORE MANUSCRIPTS WRITTEN BY THE SCRIBE OF THE LEICESTER CODEX.
}

In the Journal for April 1904, p. 445, I was able to point out on the evidence of a manuscript at Leiden that the scribe of the Leicester Codex was a man named Emmanuel of Constantinople, and that he worked for George Neville, Archbishop of York (d. r 476). I am now able to add two more to the five volumes known to have been written by him. They are at Corpus Christi College, Oxford. The first is a copy of the Lexicon of Suidas (nos. 76, 77) on paper and vellum, bound in two volumes. The first volume and perhaps a third of the socond are in Emmanuel's hand: the remainder is in the hand of Joannes Serbopoulos of Constantinople, who was working at Reading in the last years of the fifteenth century (cf. MSS C.C.C. 23,24 of 1499, 
292 THE JOURNAL OF THEOLOGICAL STUDIES

I500; no: 106 of I 495 : New College, nos. 240, 241 of 1497, no. 254 of 1494 : Trin. Coll., Camb., R. 9, 22 of 1489).

We can perhaps point to the source whence these two Greek scribes, working in England, procured a text of Suidas to transcribe. Grosseteste possessed a Suidas, and translated some selections from it (Val. Rose in Hermes $\vee$ 157): his copy was presumably bequeathed to the Oxford Franciscans with the rest of his books. The Corpus Christi MS belonged successively to William Grocyn and to John Claymond, first president of the College.

The other manuscript in the hand of Emmanuel is the Psalter, no. 19 in the same library, on paper and vellum, which was given to the College by John Claymond.

M. R. JAMES. 